\title{
DECREASE IN WEEKEND NUMBER OF STEPS IN ADOLESCENTS
}

\author{
Jana Vašíčkovái,*, Karel Frömel ${ }^{1}$, Dorota Groffik², František Chmelík ${ }^{1}$
}

${ }^{\text {I} F a c u l t y ~ o f ~ P h y s i c a l ~ C u l t u r e, ~ P a l a c k y ́ ~ U n i v e r s i t y, ~ O l o m o u c, ~ C z e c h ~ R e p u b l i c ~}$

${ }^{2}$ Academy of Physical Education, Katowice, Poland

Submitted in January, 2013

BACKGROUND: The activities with which young people spend the weekends do not support the prevalence of an active and healthy lifestyle enough. There are research evidence-based results that physical activity performed during weekend days is lower than physical activity in weekdays.

OBJECTIVE: This study aims to find out to what extent young people achieve recommended levels of physical activity on weekends and to identify possible differences with regard to nationality or gender.

METHODS: Research was realised between 2008 and 2011 at randomly selected schools in the Czech Republic and in Poland. The week long step count monitoring had 786 participants in the Czech Republic and 673 participants in Poland aged 15-16 years. The online system INDARES was used to answer questionnaires and gather data from pedometers.

RESULTS: Results showed that young people on average record lower numbers of steps on weekends compared to schooldays (difference is 1,356 steps/day; $F(1,1458)=147.61 ; p \approx .000 ; \omega^{2}=.232 * * *$ ). The most critical day of the week is Sunday. The simplified recommended amount of 11,000 steps/day is achieved by $65.93 \%$ of Czech boys and $64.73 \%$ of Czech girls (49.28\% of Polish boys and $42.92 \%$ of Polish girls) on schooldays, whereas only by $42.59 \%$ of Czech boys and $43.8 \%$ of Czech girls (40.1\% of Polish boys and $39.27 \%$ of Polish girls) on weekends. There were no significant differences between boys and girls in terms of average number of steps per day.

CONCLUSION: Reducing the weekend would certainly not secure effective advancement of physical activity and healthy lifestyle among young people, yet a change of their values and creating a habit of spending weekends actively is imperative. Use of the internet mainly in boys and use of pedometers mainly in girls are some of the tools to stimulate physical activity and healthy lifestyle in youth.

Keywords: Pedometer, internet, steps, lifestyle, recommendation.

\section{INTRODUCTION}

Weekends are a time when most young people spend leisure time according to their preferences. Also adults have, according to the Public Opinion Research Centre survey, more leisure time during Sunday (29\% indicated between 10-14 hours of leisure time in 2009) compared to Saturday, where 26\% indicated 5-6 hours of leisure time (Šamanová \& Červenka, 2011). Prevailing leisure-time activities are reading magazines, listening to music, hobbies and meeting friends and neighbours. Only $33 \%$ of the adult population mentioned exercise or sport as a leisure-time activity performed once a week. In the Czech Republic HBSC study revealed that most children spend over 2 hours a day watching TV (Kalman et al., 2010); however, comparing data from

\footnotetext{
* Address for correspondence: Jana Vašíčková, Institute of Active Lifestyle, Faculty of Physical Culture, Palacký University, tř. Míru 115, 77111 Olomouc, Czech Republic. E-mail: jana.vasickova@upol.cz
}

2002, watching TV has decreased but using computer two or more hours a day has increased in all age categories $(11,13,15$ year old children).

The majority of Polish adolescents did not reach the recommended level of PA as it is mentioned by Bergier, Kapka-Skrzypczak, Bilinski, Paprzycki, and Wojtyla (2012) and they stated that there is a disproportion between the time devoted to motor and sedentary activities (adolescents mostly watch TV, do their homework and use a computer in their free time) (Woynarowka \& Kololo, 2004). There were also found differences between urban and rural students in Poland regarding physical activity as urban students (15-17 year old) much more often declared active lifestyle, spending more hours a week performing sport and less hours spent passively on "screen viewing behaviour" (Hoffmann, Bryl, Marcinkowki, Strazynska, \& PupekMusialik, 2011). On the other hand, another Polish study done in 18 year old young adults resulted in opposite findings with rural adults having a relatively high level of physical activity (Suliburska et al., 2012). 
A study done by Sallis, Prochaska, and Taylor (2000) described several correlates of physical activity in children and adolescents. According to them, sedentary behaviour after school and on weekends (sedentary time watching TV or playing videogames) was consistently and inversely related to adolescent physical activity.

The number of steps recorded, which can indicate the level of physical activity performed is lower during weekends than on school days in adolescents (Frömel, Pelclová, Skalik, Nováková-Lokvencová, \& Mitáš, 2012; Pelclová, El Ansari, \& Vašíčková, 2010) and even lower than on school days with PE lessons. There exist some exceptions, such as children who are members of some sport club or team and participate in matches or tournaments during the weekend. Regarding certain days of the week, the number of steps differs depending on the school timetable (if there is PE lesson), afterschool physical activity, active transport to and from school and other activities that children might have.

The aim of the study is to find the day with the most and the least performed number of steps with regard to various socio-educative environment, gender and nationality. Moreover, we would like to emphasize the proportion of pupils who meet guidelines for average number of steps per day (11,000; Tudor-Locke, Craig, Beets, et al., 2011).

\section{METHODS}

\section{Participants}

The research has been conducted in the Moravia region of the Czech Republic (30 schools, 786 participants) and the Katowice region in Poland (22 schools, 673 participants) (Table 1). Every school has been visited by a uniform research team formed for the respective country. The selection of schools was based on personal contacts and the selection of classes had to correspond to students' age 15-16 years. The probands were registered in the INDARES online system (www. INDARES.com) during one lesson that took place in a computer room. They were also instructed about pedometer operation and data recording. During this first meeting students also completed the IPAQ long questionnaire which is a part of the INDARES system, but its data are not part of this study.

There were 52 schools specifically selected for participation in the research. Participants wore the pedometers for seven days all day long except for swimming, showering and sleeping. They recorded daily step counts each evening into their individual sheets and also into the online system INDARES.

\section{Research techniques}

Pedometers Digi-Walker SW 700 (Yamax Co., Yasama Corp., Tokyo, Japan) has undergone calibration and were equipped with safety snap-hook. Participants were instructed how to wear pedometers and how to operate the device. A recording sheet contained number of step counts per day, length in kilometres and number of energy expenditure in calories (input into pedometer - body weight and the length of one step). Participants were able to note into their sheet also the beginning and the end of PE lessons, training circuit or individual physical activities. The Polish version of the recording sheet has undergone the translation procedure in harmony with EORTC Quality of Life Group (Cull et al., 2002). The INDARES online system enabled analysis of recorded step counts during the week with regard to achieving the recommended amount and comparison with the group. Moreover, it enabled recording of all physical activities, including those where probands were asked to take off their pedometers.

\section{Statistics}

Software packages, Statistica CZ 9 (StatSoft, Inc., Tulsa, OK) and IBM SPSS 19 (SPSS, Inc., Chicago, IL) were used to process the results utilizing basic descriptive characteristics, cross tables and repeated multifactorial ANOVA (dependent variable - number of steps per day, dependent variable - type of day - school day, weekend, gender - male, female, nationality - Czech, Polish). Further we used "effect size" coefficients $\omega^{2}$ (Tolson, 1980) and $w$ (Sheskin, 2007) for certain com-

Table 1

Sample characteristics divided according to gender and country

\begin{tabular}{|c|c|c|c|c|c|c|c|c|c|c|}
\hline \multirow[b]{2}{*}{ Country } & \multirow[b]{2}{*}{ Gender } & \multirow[b]{2}{*}{$n$} & \multicolumn{2}{|c|}{ Age } & \multicolumn{2}{|c|}{ Weight } & \multicolumn{2}{|c|}{ Height } & \multicolumn{2}{|c|}{ BMI } \\
\hline & & & $M$ & $S D$ & $M$ & $S D$ & $M$ & $S D$ & $M$ & $S D$ \\
\hline \multirow{2}{*}{$\begin{array}{l}\text { Czech } \\
\text { Republic }\end{array}$} & Boys & 270 & 15.85 & 1.04 & 67.42 & 10.27 & 178.14 & 8.07 & 21.20 & 2.59 \\
\hline & Girls & 516 & 15.88 & 1.08 & 57.23 & 7.86 & 167.16 & 6.07 & 20.46 & 2.38 \\
\hline \multirow[t]{2}{*}{ Poland } & Boys & 207 & 15.98 & 0.91 & 66.82 & 9.83 & 176.50 & 7.93 & 21.42 & 2.72 \\
\hline & Girls & 466 & 16.40 & 0.85 & 58.43 & 9.27 & 167.86 & 7.44 & 20.69 & 2.61 \\
\hline
\end{tabular}

Note. $\quad$ BMI $=$ body mass index. 
parison. Small effect size is marked with one asterisk $(*)$, medium effect size with two asterisks $(* *)$, and large effect size with three asterisks $(* * *)$.

\section{RESULTS}

Significant difference has been found in specific weekdays $\left(F(6,1453)=61.56 ; p \approx .000 ; \omega^{2}=.111^{* *}\right)$ as well as in interaction with countries and genders $(F(3$, $\left.1455)=5.01 ; p \approx .002 ; \omega^{2}=.008\right)$. These differences are not regarded as practically significant. Boys and girls in both countries showed the lowest step counts on Sundays, where the step counts were significantly lower compared to all other days of the week (Table 2). On Saturdays the recorded step counts were significantly lower compared to Fridays. Czech boys and girls recorded the highest step counts on Fridays, which was not observed in Polish boys and girls.

During the weekend there appears a decrease of the number of steps measured in both genders in both central European countries. Overall results of average daily step counts on schooldays (Figure 1) do not show significant difference between Czech boys and girls $(p<.854)$ or between Polish boys and girls $(p<.268)$. Insignificant difference is found also in the average number of steps on weekend days in Czech $(p<.425)$ and Polish $(p<.566)$ boys and girls. Boys and girls from both countries were more physically active on an average schoolday, compared to an average day of the weekend $\left(\mathrm{F}(1,147)=147.61 ; p \approx .000 ; \omega^{2}=.232 * * *\right)$.

The recommended amount of 11,000 steps per day (Tudor-Locke, Craig, Beets, et al., 2011) was achieved by almost two thirds of Czech boys and girls on schooldays $\left(\chi^{2}=62.83 ; p \approx .000 ; w=.208 * * *\right)$ (Figure 2).

Table 2

Average numbers of steps per certain day

\begin{tabular}{lcccccccc}
\hline \multirow{2}{*}{$\begin{array}{l}\text { Country } \\
\text { Gender }\end{array}$} & & \multicolumn{7}{c}{ Day $M(S D)$} \\
\cline { 3 - 8 } \multicolumn{1}{c}{ Czech } & 270 & Monday & Tuesday & Wednesday & Thursday & Friday & Saturday & Sunday \\
Boys & & $(4,600$ & 12,252 & 12,445 & 12,503 & 13,940 & 11,383 & $\mathbf{9 , 8 9 8}$ \\
Czech & \multirow{2}{*}{516} & 11,726 & 11,959 & 12,059 & 12,507 & 14,255 & 12,083 & $\mathbf{9 , 7 5 6}$ \\
Girls & & $(4,565)$ & $(4,598)$ & $(4,976)$ & $(4,738)$ & $(5,372)$ & $(6,073)$ & $(5,348)$ \\
Polish & \multirow{2}{*}{207} & 11,550 & 10,766 & 11,662 & 10,978 & 11,568 & 10,645 & $\mathbf{9 , 3 0 1}$ \\
Boys & & $(4,714)$ & $(4,828)$ & $(5,143)$ & $(4,530)$ & $(5,236)$ & $(5,885)$ & $(5,438)$ \\
Polish & \multirow{2}{*}{466} & 10,955 & 10,397 & 10,584 & 11,500 & 11,524 & 10,697 & $\mathbf{9 , 6 9 5}$ \\
Girls & & $(4,813)$ & $(4,992)$ & $(4,241)$ & $(4,839)$ & $(4,634)$ & $(5,385)$ & $(5,293)$ \\
\hline
\end{tabular}

Note. $\quad M=$ mean number of steps per day.

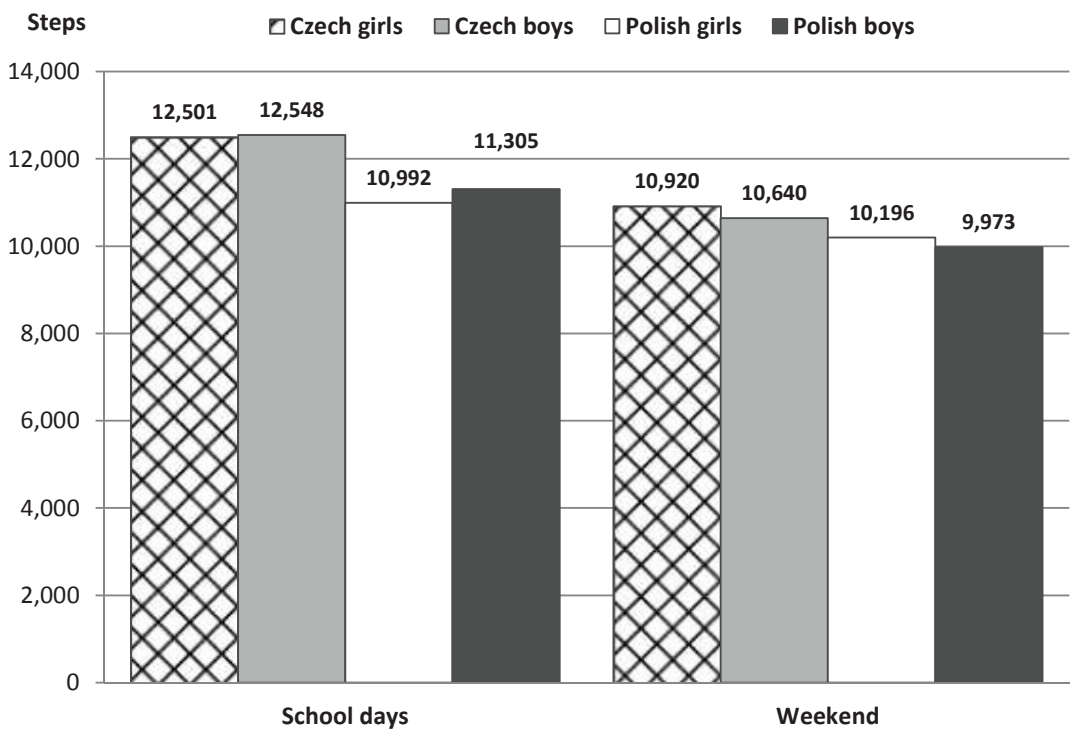

Figure 1. Average number of steps per period of week in Czech and Polish pupils 


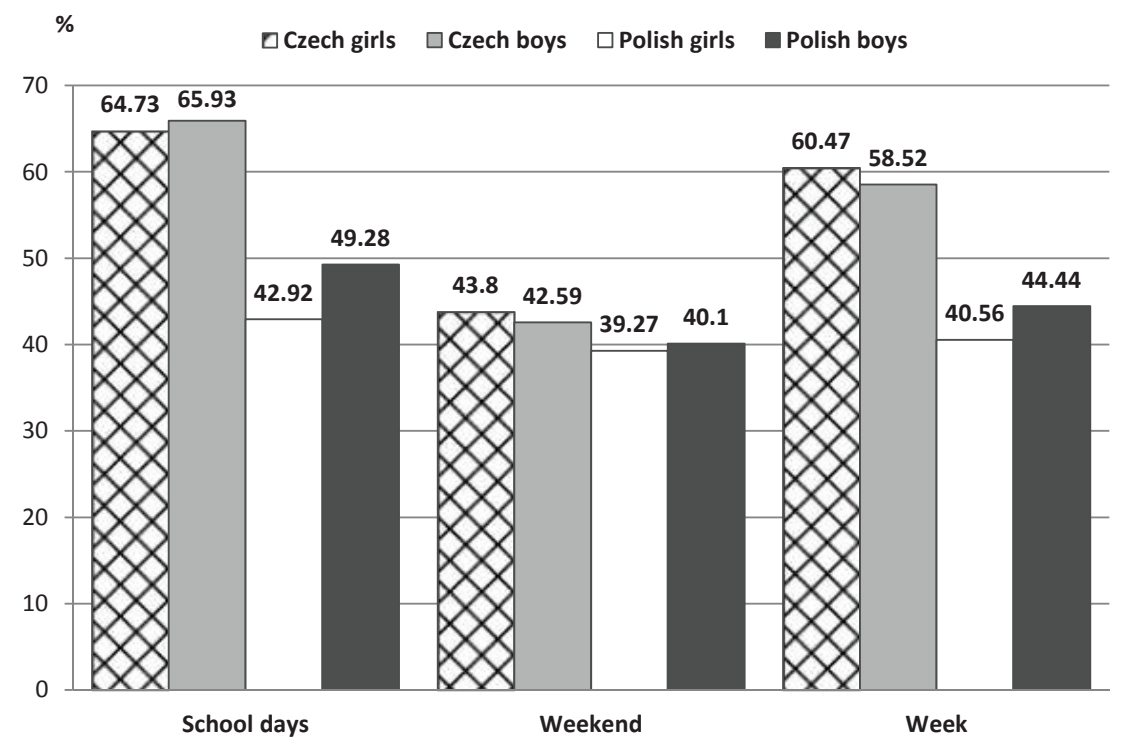

Figure 2. Percentage of Czech and Polish pupils meeting 11,000 daily steps recommendation

Slightly worse results in achieving this recommendation can be observed in Polish boys (49\% of them meets the recommendation) and Polish girls (43\% of them meets the recommendation) on schooldays. There are no differences between Czech and Polish boys and girls on weekends $\left(\chi^{2}=2.37 ; p=.499 ; w=.038^{*}\right)$. More than a half of all the boys and girls in both countries do not achieve the recommended daily step count on weekends. The achievement rate on an average day of the week $\left(\chi^{2}=48.66 ; p \approx .000 ; w=.183^{* * *}\right)$ confirms significant difference between Czech and Polish adolescents and an insignificant difference between boys and girls of both countries in achieving this recommendation.

\section{DISCUSSION}

Weekend time is very special part of a week and people can use it in very different ways according to their interests. It would be very challenging for everyone to think about a healthy lifestyle and do something to achieve it. In our study, we focused on adolescents' everyday physical activity monitored by pedometers and expressed as step counts per day with special attention to weekend days.

The most interesting finding is very low physical activity of Czech and Polish boys and girls on Sundays. None of the groups did on average reach even the generally recommended 10,000 steps $\cdot$ day $^{-1}$ (Pangrazi, Beighle, \& Sidman, 2003; Tudor-Locke, Craig, Beets, et al., 2011); this amount of steps is recommended for an adult population. This fact was not caused by Sunday being the last day of the monitoring process, be- cause the 7 day monitoring periods started on different schooldays to reflect the needs of schools. Compensation of the difference between Czech and Polish adolescents can be also affected by different approaches to Sunday religious activities in both countries. Church attendance in both countries significantly differs (Vávra, 2009). However, the effect of religious activities on daily physical activity in Poland would require a specific research. Other factors might have influenced low number of steps in Sunday. For example, there could be the possibility to sleep longer (especially in youths who often spend Saturday nights in bars or pubs), some of the students may be preparing and studying for their education, spending more time with their friends or family members, and generally Sunday is assumed to be a rest day. The highest number of steps recorded in Czech girls on Fridays is to be credited mostly to dancing activities (disco, clubs or autumn dancing lessons), which are the most popular physical activities among adolescent girls in the Czech Republic (Kudláček \& Frömel, 2012).

In a study by Biddle et al. (2009) done in CentralEastern European youth (mean age 15.5 years) we can find parallels with our investigation. Sedentary behaviour prevails in both genders during weekend days. They found that boys spent more time than girls on technological sedentary behaviour, while girls showed spent more time than boys on sedentary socializing behaviour.

Significant differences between Czech and Polish adolescents on schooldays are surprising; given the fact that Polish educational system creates better conditions for participation in school Physical Education lessons (the possibility of having four PE lessons a week) (Czyz 
\& Torila, 2012). Moreover, it have been Polish schools, where girls participating more in PE lessons had shown more overall daily physical activity compared to girls with lower participation in PE lessons (NovákováLokvencová, Skalik, Frömel, \& Górna- Łukasik, 2011).

Elimination of differences in physical activity between boys and girls expressed by daily step counts is consistent with other studies (Groffik, Frömel, \& Pelclová, 2008; Hardman, Horn, \& Rowlands, 2009; Tudor-Locke, Craig, Cameron, \& Griffiths, 2011; TudorLocke, McClani, Hart, Sisson, \& Washington, 2009).

Although the minimum recommended daily step count is not achieved by more than a third of Czech adolescents and more than a half of Polish adolescents, they are still considered active walkers. Compared to other studies, boys and girls from European and Western Pacific region had significantly more steps $\cdot$ day $^{-1}$ (weighted) than young people from the U. S. and Canada (Beets, Bornstein, Beighle, Cardinal, \& Morgan, 2010).

\section{Strengths and limits of the study}

The most important positive aspect of the study is the ability to compare weekly physical activity of boys and girls in different economic, psychosocial and educational settings. Also the fact that preparation, execution and result processing was carried out by a uniform research team played a strong role. Immediate feedback, delivered through the INDARES online system supported participants' compliance with the research.

There is a disproportion between the number of boys and girls analysed. The problem is that we analysed only data that were completed for 7 consecutive days. If there was some missing value such student/ data were deleted from our analysis. We think that significantly lower number of participating boys is a result of more positive attitude of girls towards wearing a pedometer (responsibility for the whole monitored period) and thus their larger interest in healthy lifestyle. Organisation of the research included only half a day of trial pedometer wearing, which is not sufficient to get accustomed to the new feeling. Differences between boys and girls have been minimally affected by this. We did not study other factors that may influence performing physical activities for example weather conditions (Duncan, Hopkins, Schofield, \& Duncan, 2008; Suminksi, Poston, Market, Hyder, \& Sara, 2008), season (Pieró-Veler, Devís-Devís, Beltrán-Carrillo, \& Fox, 2008), and environment (Davison \& Lawson, 2006; Ding, Sallis, Kerr, Lee, \& Rosenberg, 2011; Nelson, Gordon-Larsen, Song, \& Popkin, 2006).

\section{CONCLUSION}

From one week-long monitoring of physical activity with the use of pedometers in adolescents we obtained data through INDARES online system and completed individual sheets. A decrease of physical activity expressed by average number of steps during the weekend in 15-16 year old adolescents in Central Europe was found to be the main findings from the study. Ways of spending weekends currently common in adolescents do not support prevalence of healthy lifestyle and physical activity. Less than $44 \%$ of girls and boys in the Czech Republic and Poland did not reach recommended amount of steps during the weekends. The results are appealing to community programme organisers and parents to raise PA during the weekends, mainly on Sundays.

We realise that spending weekends in front of a monitor does not support sufficient prevalence of physically active and healthy lifestyle. It is necessary to warn parents and community clubs, organisations or even regional or local municipalities to support weekend events focused on sports and physical activity for all.

\section{ACKNOWLEDGMENTS}

This study was supported by the research grant of the Ministry of Education, Youth and Sports of the Czech Republic [MSM 6198959221], and by the ECOP project "Strengthening scientific potential of the research teams in promoting physical activity at Palacky University” reg. no. CZ.1.07/2.3.00/20.0171.

\section{REFERENCES}

Beets, M. W., Bornstein, D., Beighle, A., Cardinal, B. J., \& Morgan, C. F. (2010). Pedometer-measured physical activity patterns of youth: A 13 country review. American Journal of Preventive Medicine, 38(2), 208-216.

Bergier, J., Kapka-Skrzypczak, L., Bilinski, P., Paprzycki, P., \& Wojtyla, A. (2012). Physical activity of Polish adolescents and young adults according to IPAQ: A population based study. Annals of Agricultural and Environmental Medicine, 19(1), 109-115.

Biddle, S. J. H., Soos, I., Hamar, P., Sandor, I., Simonek, J., \& Karsai, I. (2009). Physical activity and sedentary behaviours in youth: Data from three Central-Eastern European countries. European Journal of Sport Science, 9(5), 295-301.

Cull, A., Sprangers, M., Bjordal, K., Aaronson, N., West, K., \& Bottomlex, A. (2002). EORTC quality of life group. Translation procedure. Brussels: EORTC. 
Czyz, S. H., \& Toriola, A. L. (2012). Polish children's perception and understanding of Physical Education and school sports. Journal of Teaching in Physical Education, 31(1), 39-55.

Davison, K., \& Lawson, C. (2006). Do attributes in the physical environment influence children's physical activity? A review of the literature. International Journal of Behavioral Nutrition and Physical Activity, 3(1), 19.

Ding, D., Sallis, J. F., Kerr, J., Lee, S., \& Rosenberg, D. E. (2011). Neighborhood environment and physical activity among youth: A review. American Journal of Preventive Medicine, 41(4), 442-455. doi: 10.1016/j.amepre.2011.06.036

Duncan, J. S., Hopkins, W. G., Schofield, G., \& Duncan, E. K. (2008). Effects of weather on pedometerdetermined physical activity in children. Medicine \& Science in Sports \& Exercise, 40(8), 1432-1438.

Frömel, K., Pelclová, J., Skalik, K., Nováková-Lokvencová, P., \& Mitáš, J. (2012). The association between participation in organised physical activity and level of physical activity and inactivity in adolescent girls. Acta Universitatis Palackianae Olomucensis. Gymnica, 42(1), 7-16.

Groffik, D., Frömel, K., \& Pelclová, J. (2008). Pedometers as a method for modification of physical activity in students. Journal of Human Kinetics, 20, 131-137.

Hardman, C. A., Horne, P. J., \& Rowlands, A. V. (2009). Children's pedometer-determined physical activity during school-time and leisure-time. Journal of Exercise Science and Fitness, 7(2), 129-134.

Hoffmann, K., Bryl, W., Marcinkowski, J. T., Strazynska, A., \& Pupek-Musialik, D. (2011). Estimation of physical activity and prevalence of excessive body mass in rural and urban Polish adolescents. Annals of Agricultural and Environmental Medicine, 18(2), 398-403.

Kalman, M., Sigmund, E., Sigmundová, D., Hamřík, Z., Beneš, L., Benešová, D., ... Czémy, L. (2010). Národní zpráva o zdravi a životním stylu dètí a školá$k \dot{u}$ - studie HBSC [National report about health and lifestyle of children and pupils - HBSC study]. Olomouc: Univerzita Palackého.

Kudláček, M., \& Frömel, K. (2012). Sportovní preference a pohybová aktivita studentek a studentů střednich škol [Sport preferences and physical activity in high school students]. Olomouc: Univerzita Palackého.

Nelson, M. C., Gordon-Larsen, P., Song, Y., \& Popkin, B. M. (2006). Built and social environments: Associations with adolescent overweight and activity. American Journal of Preventive Medicine, 31(2), 109-117. doi: 10.1016/j.amepre.2006.03.026

Nováková-Lokvencová, P., Skalik, K., Frömel, K., \& Górna-Łukasik, K. (2011). An analysis of school physical activity in adolescent girls. Acta Universitatis Palackianae Olomucensis. Gymnica, 41(2), 65-70.

Pangrazi, R. P., Beighle, A., \& Sidman, C. L. (2003). Pedometer power: 67 lessons for K-12. Champaign, IL: Human Kinetics.

Peiró-Velert, C., Devís-Devís, J., Beltrán-Carrillo, V. J., \& Fox, K. R. (2008). Variability of Spanish adolescents' physical activity patterns by seasonality, day of the week and demographic factors. European Journal of Sport Science, 8(3), 163-171.

Pelclová, J., El Ansari, W., \& Vašíčková, J. (2010). Study of day, month and season pedometer-determined variability of physical activity of high school pupils in the Czech Republic. Journal of Sports Science \& Medicine, 9(3), 490-498.

Sallis, J. F., Prochaska, J. J., \& Taylor, W. C. (2000). A review of correlates of physical activity of children and adolescents. Medicine \& Science in Sports \& Exercise, 32(5), 963-975.

Sheskin, D. J. (2007). Handbook of parametric and nonparametric statistical procedures. Boca Raton, FL: Chapman \& Hall/CRC.

Suliburska, J., Bogdanski, P., Pupek-Musialik, D., GlodNawrocka, M., Krauss, H., \& Piatek, J. (2012). Analysis of lifestyle of young adults in the rural and urban areas. Annals of Agricultural and Environmental Medicine, 19(1), 135-139.

Suminski, R., Poston, W., Market, P., Hyder, M., \& Sara, P. (2008). Meteorological conditions are associated with physical activities performed in openair settings. International Journal of Biometeorology, 52(3), 189-197.

Šamanová, G., \& Červenka, J. (2011). Czech and leisure time. SocioWeb, 7/8, 1-3.

Tolson, H. (1980). An adjunct to statistical significance: $\omega^{2}$. Research Quarterly for Exercise \& Sport, 51(3), 580-584.

Tudor-Locke, C. E., Craig, C., Beets, M., Belton, S., Cardon, G., Duncan, S., ... Blair, S. (2011). How many steps/day are enough? For children and adolescents. International Journal of Behavioral Nutrition and Physical Activity, 8(1), 78. doi: 10.1186/14795868-8-78

Tudor-Locke, C. E., Craig, C., Cameron, C., \& Griffiths, J. (2011). Canadian children's and youth's pedometer-determined steps/day, parent-reported TV watching time, and overweight/obesity: The CANPLAY Surveillance Study. International Journal of Behavioral Nutrition and Physical Activity, 8(1), 66.

Tudor-Locke, C. E., McClain, J., Hart, T., Sisson, S., \& Washington, T. (2009). Expected values for pedometer-determined physical activity in youth. Research Quarterly for Exercise and Sport, 80(2), 164-174. 
Vávra, M. (2009). Jak zjištovat návštěvnost bohoslužeb? Problémy s měřením náboženského fenoménu [How to measure church attendance. Problems with measuring of religious phenomenon]. Naše společnost, 7(1), 32-39.

Woynarowska, B., \& Kololo, H. (2004). Aktywność fizyczna i zachowania sedenteryjne nastolatków [Physical activity and sedentary behavior of teenagers]. Remedium, 6(8). Retrieved from http://www. remedium-psychologia.pl/2004_6_8.htm

\section{POKLES POČTU REALIZOVANÝCH KROKŮ $O$ VÍKENDECH U ADOLESCENTŮ}

\author{
(Souhrn anglického textu)
}

VÝCHODISKA: Trávení víkendových dnů mladých lidí nepodporuje dostatečně prevalenci pohybově aktivního a zdravého životního stylu. Existují výzkumné studie potvrzující, že víkendová pohybová aktivita je nižší než pohybová aktivita $\mathrm{v}$ pracovních dnech.

CÍLE: Cílem studie je zjistit, jak plní mladí lidé doporučení $\mathrm{k}$ pohybové aktivitě ve víkendových dnech a jaké jsou rozdíly $\mathrm{v}$ jejich průměrném denním počtu kroků vzhledem k pohlaví a národnosti.

METODIKA: Výzkum byl realizován v letech 2008 až 2011 na náhodně vybraných školách v České republice a v opolsko-slezském/katowickém regionu v jižním Polsku. Týdenní monitorování počtu kroků absolvovalo v České republice 786 a v Polsku 673 žáků. K vyplnění dotazníků a záznamu údajů z pedometrů byl využit internetový systém INDARES.

VÝSLEDKY: O víkendech mladí lidé nachodí v průměru méně kroků než ve školních dnech (rozdíl je 1356 kroků/den; $F(1,1458)=147,61 ; \quad p \approx 0,000$; $\left.\omega^{2}=0,232 * * *\right)$, nejkritičtější den $\mathrm{z}$ celého týdne je neděle. Zjednodušené doporučení 11000 kroků/den plní ve školních dnech 65,93 \% českých chlapců a $64,73 \%$ českých děvčat $(49,28 \%$ polských chlapců a $42,92 \%$ polských děvčat), zatímco ve víkendových dnech pouze 42,59 \% českých chlapců a 43,8 \% českých děvčat (40,1 \% polských chlapců a 39,27 \% polských děvčat). Mezi chlapci a děvčaty nebyly zjištěny významné rozdíly v průměrném počtu kroků za den.

ZÁVĚRY: Omezení víkendových dnů by zajisté nezajistilo účinné prosazování pohybově aktivního a zdravého životního stylu mladých lidí, avšak změna hodnotové orientace a návyk na pohybově aktivní trávení víkendových dnů je u mladých lidí nezbytná. Využití internetu k podněcování PA zejména u chlapců a využívání krokoměrů zejména u děvčat je jednou z možností prosazování pohybově aktivního a zdravého životního stylu u mladých lidí.

Klíčová slova: krokoměr, internet, kroky, životní styl, doporučení k pohybové aktivitě. 